い，之はかかる心藏にあつては, 左心房の病的變化の第，

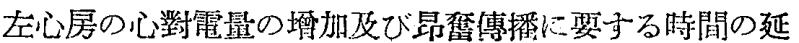
長が考えられるが，その最大の時期は在心房心對雪量の 最大の時期より遥汃に遮くなる第，兩心房の心對電望の

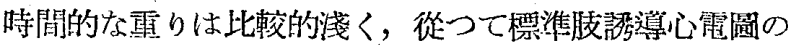
$\mathrm{P}$ 波の解析による心對電鲑に大なる變化を認めないわけ である。

4）心對電方向量の持縜時間は相當程度延長してい る. 右心房力゙健常な際は，P波の解析により知られる心 對䉓方向量の終る時期は，左心房の昂鹪傳達が終る時期 と一致するものであり，然してかかる病的左心房に於い ては，之が相當程度逮延するによる故である。

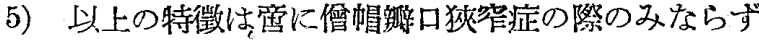
一般に左心房の肥大及び攄張の際に屯同樣に考えられる ゆのであるから，藷都は，高安が左心房優勢なる語を提 唱するのに同意したいと思う。

\section{References}

1) $9,16 \& 30)$ : See 3rd Report: This Journal 13, 210, (1949)

31) 32, 35, 37, 38 \& 39): See 4th Report: Ebenda 13. 212, (1949)

40) Fujito: This Journal 13. 212 (1949)

41) Takayasu: Ebenda 3, 381 (1987)

42) Shimizu : Ebenda 5, 164 (1039)

\title{
Experimental Arteriosclerosis in the Lungs, especially on Research by Reconstructing Model. Part I. Adrenalin-Arteriosclerosis.
}

By

Ichiro Kawakami.

The Pathological Institute of the Kumamoto Medical College.

(Director: $K$. Suzue, M.D.)

\section{Preface}

The cause of arteriosclerosis, of course, is complicated and divergent, but many scholars agree that local elements of the blood ressels play a great part for causing arteriosclerosis. Therefore on the research for the arteriosclerosis, its stereoobserva$t^{\text {ion }}$ seens very important to investigate the true nature of its attack.

We notice that some researches were made so far on the arteriosclerosis of central artery system, basing on such a stereo-standpoint, but I have never met with such research work on the arteriosclerosis in the lungs.

So I researched the arteriosclerosis in the lungs based on stereo-standpoint, as a partial research of "Experimental Researches on Arteriosclerosis", that is the main theme of our institute in these years.

In the 1st part, I have observed by reconstructing model on the pulmonary arteries of the rabbits that had been injected adrenalin, and this adrenalinmethod was discovered by Josué (1903).

\section{Materials and Methods}

The materials which $I$ have employed, were the same as Dr. Terai's, a senior of our institute. He used them in his research on "Abnormal Function of the Male Sexual Organ and Experimental Arterio- sclerosis".

I picked out No. 41, 115 (both contrast) and 38, 1 (the testicles enucleated) among the rabbits that had been injected adrenalin to accelerate arteriosclerosis and also injected Enarmon or enucleated the testicles to compound abnormal function of the male sexual organ.

I fixed these lungs of the rabbits in formalin and made them into several hundred series of sec-, tions every 20 micron thickened after celloidin-imbedding. Staining was of the usual process. And I made a some reconstructing models, delineating section by section. As occasion demanded wax-models were made.

And the pulmonary arteries that I have observed, belong to the smaller group.

\section{Results}

I am going to state the results of this research :

1. Adrenalin-arteriosclerosis of various changes are observed on the pulmonary arteries of the rabbits by continual injections of adrenalin. Namely, there are muscular thickening of the media, thickening, degeneration etc. of the intima. The adrentitia does not seem to react on arteriosclerotic changes throughout the course of the blood vessels.

2. The local relations of the occurrence and progression of the adrenalin-arteriosclerosis seem to 
be almost ruled by a regular fundanental principle. Concretely, they are as follows:

a. Sclerotic changes are generally appeared powerfully on the side of convex surface of the blood vessel's curvature.

b. On bifurcating parts, we can generally see more powerful sclerotic changes than the other parts.

In stating in detail, sclerotic changes begin to occur from lower on the inside thigh of bifurcating parts, …. farther the distance to bifurcating parts is, more powerful they are $\cdots . .$. , and they become just on the bifurcating part most powerful, and generally disappear soon after completion of bifurcation. And sclerotic changes usually occur more powerfully upon the upper and lower parts of the inside thigh of the bigger bifurcating branch.

3. A considerable large number of aneurysms can be seen in places. The rate of their occurrences does not always agree with the degree of arteri-

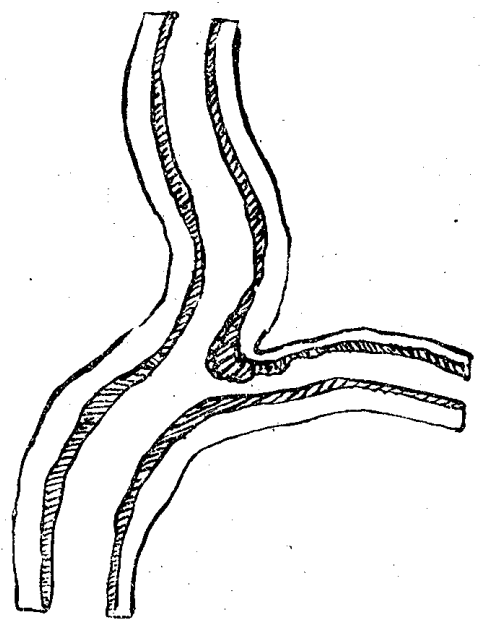

Fig. 1 Thickening of the intima on the inside thigh of bifurcating branch.
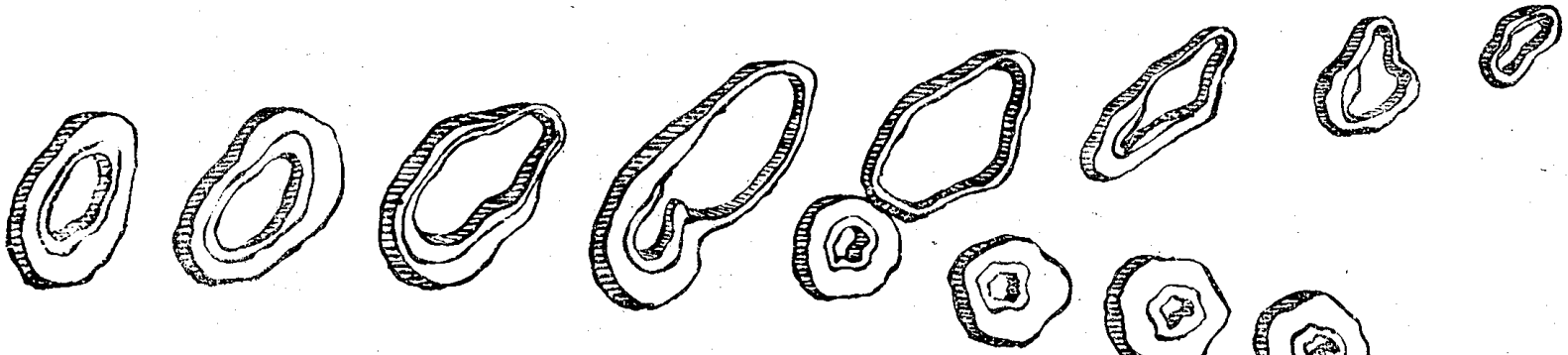

Fig. 2 Schema of miliary aneurysm on bifurcating part.

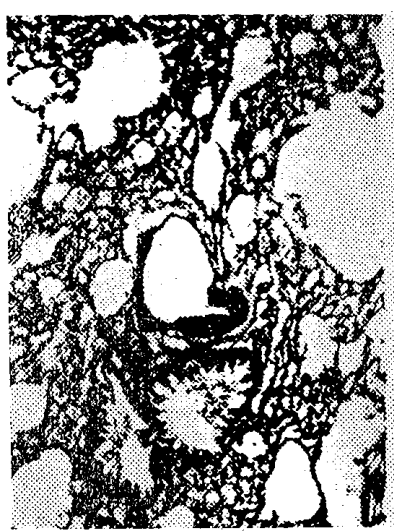

A

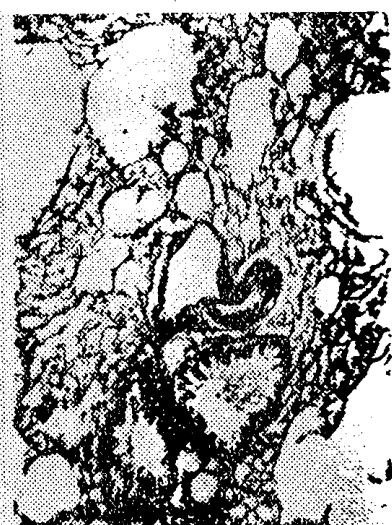

$\mathrm{B}$

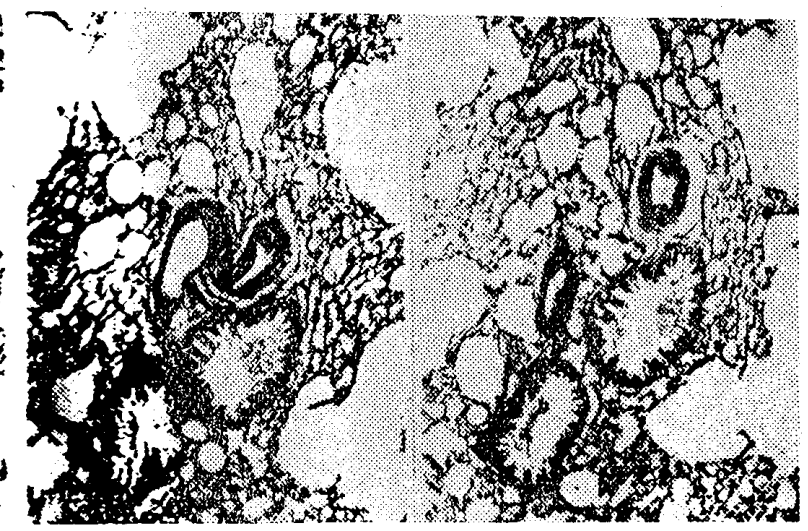

C
$\mathrm{D}$

Fig. 3 A. B. C. D.: Miliary aneurysm on bifurcating part. 
osclerosis. Especially I have observed that most of them had been formed on the excapillary arteries almost on the whole parts. And such aneurysms are almost formed on bifurcating parts as their central points : namely, on one side it is spreading on to both branches, appearing immediately before bifurcation, on the other side it is spreading only on one side of the branch, appearing before bifurcation. So it can be seen that their localizations are irre. gular.

\section{Discussion}

We see some minute researches our pioneers had made on the fact and its genesis of some kinds of changes, specially arteriosclerotic changes which had been occured on the pulmonary arteries of the rab. bits by the continual injections of adrenalin (Kiyono and Higashihara, Shin, Haga, Suzue and Okamura, Fujisaki, Shinohara).

But we clo not hear such a research as the one I have made recently, observing the relation between the local elements of the blood vessels and the occurrence or progress of adrenalin-arteriosclerosis.

Indeed we hear about some researches here and there concerning this disease of the central artery system and some organ's arteries, basing on stereostandpoint (Thoma, Anitschkou, Kodama, Tanaka).

Surveying the researches by these scholars, it will be noticed that there is a common rule naturally. That is, the occurrence and progress of arteriosclerotic changes which are controled by stereo-local structure of the blood vessels themselves.

Concretely arteriosclerosis is noticed to occur and progress on curving parts and bifurcating parts of the blood vessels. The result that I have obtained in this research for experimental arteriosclerosis in the lungs tallys with the researches as above mentioned also. In my case, …..adrenalin-arteriosclerosis in the rabbit's lungs ...... sclerotic changes are observed to occur powerfully on the convex surface of the curvature or bifurcating parts (specially on bigger branch) of the blood vessels. We may naturally assent to this fact by common sense, and it will be understood that sclerotic changes would begin to occur on the parts, having collisions of blood stream most powerfully.

In the followings, the aneurysm which research is most interesting and suggestionable will be discussed.

Well, according to the books of medicine, adre- nalin has the action, dilating the pulmonary artery (of rabbit in my case). Looking over many literary works, we could see clearly that the affecting parts lied on the peripheral arteries (Takashima, Ito, Takino and Isukara, Tanaka). But about the genesis of this dilating action, they have not the established theory, saying primary or secondary. Just at this time, I have accidentally discovered the occurrence of aneurysms as a byproduct while making the research work of arteriosclerosis. And their localiizations are on the excapillary arteries and the arteries smaller than medium sized, moreover the centers of these aneurysms are almost on bifurcating parts of the blood vessels.

Hitherto I have never heared any one had succeeded in creating aneurysm experimentally in the rabbit's lungs.

Anyway it is natural for me to deduce that there will be some relations between the facts in the literature as above mentioned and $m y$ aneurysm.

Then I should like to understand that the occurrence of this aneurysm would be depended on collapse of the peripheral arteries, because perhaps they couldn't continue their changeable dilatation for continual lypertension, according to adrenalin-injecting.

Considering reversely, this dilatation of the peripheral arteries might be considered adaptation for the regulation of blood pressure.

The knowledge that I have acquired from the aneurysms that I accidentally discorered recently which are formed in arteriosclerotic lungs of rabbit, will give suggestions on the morphological study for function of the pulmonary artery in future, I beliere.

\section{Conclusion}

The following is the conclusion as the result of $11 \mathrm{y}$ discussion about this research as above mentioned.

1. Adrenalin-arteriosclerosis in various degrees are caused on the pulmonary arteries of the rabbits by means of continual adrenalin-injection. Namely, there are thickening of the media, tickening, and degeneration etc. of the intima. But the adventitias did not indicate clear reaction for arteriosclerotic changes throughout the course of the blood vessels.

2. The occurrence and progress of adrenalin-arteriosclerosis are controled under the stereo-local elements of the blood vessels themselves. In other 
words, that will occur on the parts of the blood vessels, recieving greatly dynamic effects of blood stream. Concretely that will occur on the following parts :

a. On the side of convex surface of the blood vessels, the greater the curving the more powerful is the disease.

b. On bifurcating part generally occurs sclerotic change more powerfully. In stating minutely, adrenalin-arteriosclerosis occurs on lower from the inside thigh of branch before bifurcating part ...... the farther the distance to the point of bifurcation, the more powerful is its occurence. ........ becomes most powerful just on the point of hifurcation and generally disappears soon after the completion of bifurcation. And this arteriosclerosis occurs more powerfully on the inside thigh of the bigger bifurcating branch.

3. There is a tendency that a large number of aneurysms are caused on the rabbit's pulmonary arteries by means of the continual adrenalin-injection. Their localizations are on the arteries smaller than medium sized and the rate of the occurrence do not always consist with the degree of arteriosclerotic changes

At laying down my pen, I express my gratitude to Porf. Suzue, ny teacher for his kind guidance and revising.

\section{lieference}

1. Josué : C. r. Soc. Bio., 384. (1908)

2. Masanobu Terai : Nippon J. of Angio-Cardiology 8, 442. (1943)

3. Kiyono and Higashihara: K yoto J. of Med. Ass. 15, 1002. (1918)

4. Seiu Shin: J. of Med. Col. in Keijo, 1, 73. (1931)

5. Yoshio Haga : Holkuetsu J. of Med. Ass., 49, 274. (1934)

6. Suzue and Okamura:-J. of Const. Med., 10, 181. (1941)

7. Fujihiko Fujisaki : Manšhu Gunidan Zasshi, 49,7. (1942)

8. Kikyo Shinohara: Ciba J. of Med. Ass., 11, 184. (1933)

9. Thoma, R.: Virchow' Arch., 245, 78. (1925)

10. Anitschkow, N.: Kyoto J. of Med. Ass., 27, 823. (1980)

11 Makoto Kodama: Nippon No Ikai, 16,41. (1926)

12 Jiro Tanaka : not published.

13. Sainosuke Takeshima: Oosaka Iji Shinshi, 7, 1494. (1936)

14. Shigehiko Ito: Fol. Endoc. Jap., 12, 623. (1936)

15. Takino and Isukawa: Fol. Endoc. Jap., 17, (1941)

16. Shigeo Tanaka: Fol. Endoc. Jap., 18, 564. (1942)

肺腈に於ける實驗的動胍硬化症特に解形複成模型に上る立體的研究

第1 編 アドレナリン動脈硬化症に就て

\author{
川上一朗

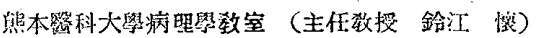

動脈硬化症の發症に對し血管の局所要約が㭢めて重大 なる役割を演ずるものなることは學者の等しく認めると ころである，即ち立體的欟察の重要なる所以である．余 は我滧室に於ける年來の主要的究題目心る"動脈硬化 症の實驗的㸴究"/の一端として從來この方面の文献乏し

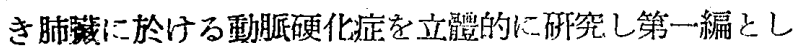
てアドレナリン處置群に於ける論說を淮めたのである. 即ち動脈硬化症催發趒置としてアドレナリン連續注射を 施行せる家雨肺藏に就き之を檴形複成模烈として觀察し 凡そ次の如き事實を明らかにした。

1.アドレナリン連續注射を施行坔る家乘肺藏動脈は程 々の程度のアドレナリン型碩變性變化を莠迊する. 即ち

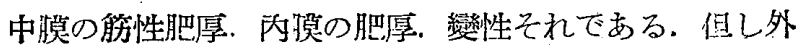

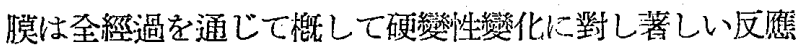
を示さないよでうある.

2.アドレナリン型硬變性變化の登現梨强は賞に血管自
體の立體的局所的要行に支配される，採言すれば血流に 久る力學的影響の起大なる部位に發現する，具骾的に言 えば

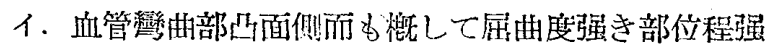
く湎現宁方。

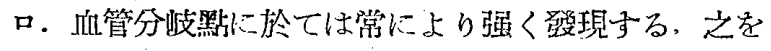
詳言すれば.

アドレナリン㤠硬戀性戀化は分政點前分汥脚内股

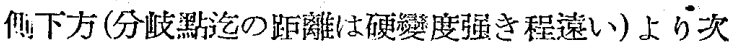

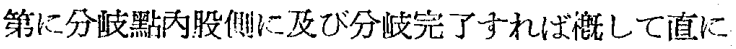

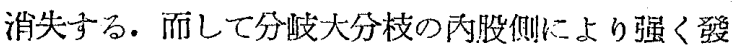
現するのを涌例とする。

3.アドレナリン連續注射により家棸肺臟動脈管には動

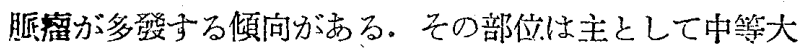

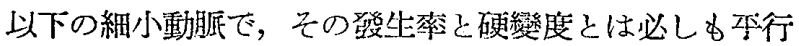
しない. 